Social Work/Maatskaplike Werk Vol 50 No 3; Issue 7

http://socialwork.journals.ac.za/pub . http://dx.doi.org/10.15270/50-2-408

PREPARING SOCIAL WORKERS FOR ALTERNATIVE DISPUTE RESOLUTION IN CARE AND PROTECTION CASES

Carmel R Matthias, University of KwaZulu Natal, Durban, South Africa

Abstract

The Children's Act 38 of 2005 contains provisions enabling utilisation of alternative dispute resolution (ADR) in cases involving children. This article focuses on the specialised training required to prepare social workers to be effective ADR practitioners. By drawing on comparative data, the article demonstrates that it is essential for social workers to receive such training in South Africa. The nature of the training that would be required to empower South African social workers to be effective ADR facilitators in care and protection cases is explored. Proposals for a South African training programme are put forward. 


\section{PREPARING SOCIAL WORKERS FOR ALTERNATIVE DISPUTE RESOLUTION IN CARE AND PROTECTION CASES}

\section{Carmel R Matthias}

\section{INTRODUCTION}

The Children's Act 38 of 2005 (the Act) allows for utilisation of a variety of forms of alternative dispute resolution (ADR). Children's courts are given discretion to order ADR when it appears appropriate for cases involving children (sections 49, 69, 70 \& 71). The ADR options mentioned in the Act include mediation, pre-hearing conferences, family group conferences and, in a broad catch-all phrase, "other lay forums" (for a detailed discussion see Schäfer, 2011:323-328). The inclusion of ADR in the Act is a positive development. As is well-known, in many cases ADR is much better for addressing problems involving families and children than court litigation (De Jong, 2009; Firestone \& Weinstein, 2004; Jordan, 2009). It is true that in some cases abusive behaviour by family members, extreme power imbalances between parties, or urgency considerations in obtaining a binding decision may render ADR inappropriate. However, internationally it is being increasingly utilised because of its many positive features. These include flexibility of processes, cost saving, increased ownership of outcomes by families, and potential for opening up channels of communication (Australian Law Reform Commission, 2012).

Although statistical data are not available, it is clear from comments by practitioners that relatively little care and protection ADR has taken place since the commencement of the Act (Gallinetti, 2012). For example, Child Welfare Durban and District processes many care and protection matters, but has never had any referral for ADR by a magistrate since the coming into force of the Act (Kitching, 2014). There is little point in having South African legislation supporting ADR in children's cases unless it can be effectively implemented. Obviously, the ADR provisions in the Act can only be utilised on a significant scale if there are sufficient properly trained persons available who can conduct appropriate ADR. Domestic mediation training programmes have been available in South Africa for many years. However, they are mainly designed to assist with private parental disputes, such as those concerning child custody (see Family Life Centre, 2014; National Accreditation Board for Family Mediators, 2011). In contrast, little attention has so far been devoted to ADR requirements and training for child care and protection cases. As will be shown, because of the different considerations which tend to be relevant, there is a strong case for specialised ADR training in this field. If social workers do not ensure that their voices are heard when it comes to shaping training, professionals from other disciplines may eventually monopolise care and protection ADR (Barsky, 2001:44). That would be unfortunate because many South African social workers are potentially ideal candidates for training because of their extensive involvement with care and protection matters and their familiarity with nonconfrontational problem-solving. 
This article explores what training and related measures are required to enable significant numbers of South African social workers to provide effective ADR services as envisaged in the Act. The focus is on how best to empower social workers to provide such services in care and protection cases. A literature review was conducted as a method of data collection. The aim was to explore experiences in using ADR in child care and protection cases in other countries. In order to provide some context, the next part will briefly explore the preliminary question of what forms of ADR have most commonly been used. After that, an analysis of training methods and related frameworks is provided. In the final part of the article, and drawing upon findings from the comparative analysis, options for a South African training model are presented. Fundamental issues that will have to be resolved are identified. Some specific recommendations for training South African social workers are also provided.

\section{ADR METHODS FOR CARE AND PROTECTION CASES}

Care and protection ADR is being increasingly utilised in many countries because of its potential for resolving some of the disputes and problems which typically arise in these cases (Association of Family and Conciliation Courts Guidelines (AFCC Guidelines), 2012; Australian Law Reform Commission, 2012). Mediation and family group conferencing variants are by far the most common methods being successfully employed (Ban, 2005; Chandler \& Giovannucci, 2004; Evans, 2011; Mayer, 2009; Olson, 2009; Weigensberg, Barth \& Guo, 2009). However, a comparative review by the Australian law reform commission indicated that other less commonly utilised methods which are sometimes effective include "conferences prior to a court hearing; the role of family consultants in the Family Court; and ADR processes developed for indigenous families, such as Care Circles" (Australian Law Commission, 2012: para 23.67).

Child protection mediation (CPM) has been described as "a collaborative problemsolving process involving an impartial and neutral person who facilitates constructive negotiation and communication among parents, lawyers, child protection professionals, and possibly others, in an effort to reach a consensus regarding how to resolve issues of concern when children are alleged to be abused, neglected or abandoned" (Association of Family and Conciliation Courts Guidelines, 2012:6). Whilst this description may seem similar to mediation in a private custody dispute context, in care and protection cases a major difference is that the child welfare agency dealing with the matter on behalf of the state becomes an additional party (section 1 of the Act; see also Zaal, 2010). When involved as a party, a social worker's role is therefore to present the agency's case in the matter being mediated. However, as Hehr (2007) points out, when a social worker instead acts as a child protection ADR mediator her role needs to change significantly from that ordinarily undertaken by social workers involved as parties in care and protection cases. This is because in ordinary practice "[c]hild protection workers typically take on a role as a state agent, which may often cause parents to feel disempowered and threatened" (Hehr, 2007:454). When conducting CPM, however, social workers must remain entirely neutral and "should stress collaborative problem solving between the parties in order to negotiate the best outcome" (Hehr, 2007:454). Although children's safety and best interests remain paramount, there has to be a 
stronger emphasis in CPM on developing a plan "that satisfies all parties" (Edwards, 2009:72). So the role of social workers does need to change when they serve as care and protection mediators.

When mediation is properly conducted it has considerable potential for generating "a greater sense of teamwork and a greater understanding and ownership of resulting agreements by all involved" in care and protection cases (Association of Family and Conciliation Courts Guidelines, 2012:6). Hehr (2007:457) asserts that CPM can often be useful to "expedite permanency for the child". In terms of process, a care and protection mediator "identifies the disputed issues, develops options, considers alternatives and endeavours to reach an agreement. The mediator has no advisory or determinate role in regard to the content of the dispute, but can advise on or determine the process used to attempt resolution" (Sheehan, 2006:168). It is important to note that effective CPM requires mediators with the requisite capabilities. Edwards (2009:72) stresses that they must be sufficiently "skilled, trained and culturally competent". He noted further that the "quality of mediators is critical" for a number of reasons, including parties' confidence in their skills and judgment. He concluded that if mediators are not appropriately skilled, child protection mediation is likely to fail. Mayer (2009:17) reports similar findings on "the importance of well-trained, experienced, culturally sensitive, empathic, and skilled mediators. The skill of the mediators, rather than their specific approach (e.g. transformative, facilitative, etc.), was what was seen as critical."

Aside from mediation as a method, family group ADR forms have also been widely used for care and protection matters. Family group conferences (FGCs) were first introduced in New Zealand in the 1980s (Chandler \& Giovannucci, 2004; Huntsman, 2006; Olson, 2009). Since then, the use of FGCs and other similar family group decision-making variants have spread throughout the world (Ban, 2005; Weigensberg et al., 2009). In an FGC a social worker or other helping professional meets with a family "to develop the best possible plan for a child who is the victim of neglect or abuse. FGC places the family at the center of the welfare proceeding and helps to empower them so a solution can be reached" (Lubin, 2009:130).

There are generally three phases of an FGC. Evans (2011) describes these as follows: firstly, information sharing, which includes presentation of the facts to the family who must then be given the opportunity to ask questions. In the second phase the family is left on their own without any convenor or other professionals present to discuss possible solutions by themselves. It is particularly this stage which sets FGCs apart from other ADR methods. In the third phase, the convener re-joins the family, and final decisions and plans are agreed on. According to Lubin (2009), in New Zealand FGCs have proved to be highly effective in care and protection matters. She noted that "in $90-95 \%$ of cases in New Zealand an agreement is reached and the case never appears before a court" (Lubin, 2009:132). Ontario, which has a well-developed system of care and protection ADR, utilises a variant called family group decision-making. This is very similar and also has three phases: information sharing, family time, and development of a plan for the child (Children's Community Network (Ontario), 2014). 
Family group ADR variants all require independent convenors who understand their role in the different stages and appreciate that they are not directly involved in making decisions about a child (Brown, 2003:335). Before facilitating a family group ADR process, the convenor must complete some important preliminary functions. These are: to identify and locate family support systems, convince family and other support system members to participate, and prepare them for the process. Because the convenors need to be independent and carry out tasks that are unique, they require specialised training (Chandler \& Giovannucci, 2004).

Pre-hearing ADR conferences occur shortly before matters are due to go to court for a full hearing. The purpose is to "define the issues to be heard by the court" and if possible settle the disputes (section 69 of the Act). Pre-hearing facilitators need to be able to interact constructively with lawyers, who are likely to be present (Sheehan, 2006:168). Indigenous methods of care and protection ADR require facilitators with appropriate local cultural knowledge and language capability. Like family group methods, they tend to draw on the strengths of extended families in finding effective solutions for children (Australian Law Commission, 2012: para 23.67).

\section{TRAINING}

An overview of some selected training initiatives in other systems is provided below. For clarity, it is divided into the following sections: eligibility criteria, length of training, training content, assessment and continuing education.

\section{Eligibility criteria}

A set of care and protection ADR training guidelines developed by American courts stresses the importance of "deliberative recruitment" in the sense of careful selection of candidates (Association of Family and Conciliation Courts Guidelines, 2012:19). These guidelines further indicate that in order to obtain appropriate candidates for training, it is essential to have eligibility criteria. In a review of the literature, three broad categories of eligibility criteria emerged. Firstly, there are those which help discern individual personality/ability characteristics of candidates; secondly, criteria requiring educational qualifications; and thirdly, practice requirements which demand actual experience in working with children and/or prior ADR experience.

In considering, firstly, the individual personality/ability characteristics, it has been found in the USA that selection criteria should include whether candidates are "capable of acquiring and maintaining the skills, knowledge, ethics and qualities that are necessary ... for highly complex, legal and emotionally laden disputes involving children, their families and child protection professionals" (Association of Family and Conciliation Courts Guidelines, 2012:19). In addition, potential candidates must have good communication skills and be culturally responsive (Association of Family and Conciliation Courts Guidelines, 2012:19). Depending on intended client populations and whether indigenous ADR methods are to be utilised, cultural and linguistic competence should also be treated as enhancing the eligibility rating of prospective candidates (Chandler \& Giovannucci, 2004). 
As noted above, a second category of eligibility criteria which typically appears in training programme frameworks is formal qualification requirements relating to educational background of applicants. Most ADR training programmes require applicants to have a Bachelor's degree in a relevant professional qualification (Chandler \& Giovannucci, 2004; Cunningham \& Van Leeuwen, 2005). The Ontario Ministry of Children and Youth Services more leniently requires either a professional degree or diploma in "the social services or children's services" (Ontario Association for Family Mediation, 2014: roster eligibility). However, the California Rules of Court (2014) require that social workers intending to serve as child welfare mediators must have at least a Master's degree (rule 5.518 (e) (1)).

In addition to eligibility criteria pertaining to individual characteristics and educational background of candidates, the third category of actual practical experience in working with children and families, culturally relevant experience and prior experience in conducting ADR is also seen as important in some systems. The Ontario care and protection mediation training course referred to above provides a useful example of practice-based eligibility criteria. Candidates must have successfully completed at least 60 hours training in general family mediation. This general training must include at least 20 hours of skill-based training, 15 hours of domestic violence training, and completion of the least 10 family law mediation cases to the point of agreement amongst the parties (evidenced by a memorandum of understanding). Only after this do candidates become eligible to apply for the training course in child protection mediation. A screening committee decides who will be eligible to attend the course (Ontario Association for Family Mediation, 2014). Successful completion of a general family mediation programme as required in Ontario has the advantage of indicating that candidates have at least some of the ability characteristics needed to undertake the more specialised child protection mediation training.

\section{Duration of training}

In reviewing foreign training systems, it appears that at least 40 hours are required. For example, the California Rules of Court (2014) require that child welfare mediators must have at least 40 hours of training (rule 5.518 (e) (3)). More extensive programmes tend to specify separate components. Sometimes, a basic component is followed by a more advanced segment. Giovannucci and Largent (2009) refer to a programme starting with 40 hours of preliminary training in basic mediation, followed by 40 hours of child protection mediation training. As noted above, Ontario also has an initial requirement of general family mediation training. But it sets this as an eligibility requirement for entrance to its three-day training programme specifically on child protection mediation. In contrast, the American AFCC Guidelines (2012:19) recommend that candidates proceed directly to child protection mediation training. In the first phase of this they receive 40 hours of "didactic and experiential training" conducted by experienced trainers. This is followed by a practical "observation" component.

Hehr (2007:469) recommends extensive training. She proposed 100 hours of didactic training. She suggests that 40 hours of this be "dedicated to the particular legal issues 
involved in child protection". A further 20 hours should be spent on "sensitivity awareness" to alert trainees "to the potential emotional concerns and issues that may affect the family and the child" during child protection ADR. In relation to training specifically for FGCs, Chandler and Giovannucci (2004:228) describe training with three components: 12 hours of basic didactic or "orientation" training followed by 40 hours of practical training on FGC facilitation; the third component involves trainees in co-facilitation of five cases. Each trainee is now individually mentored. The mentor provides feedback on the trainee's performance.

\section{Content of training programmes}

Mayer (2009:18) distinguishes between training on process and on substantive issues. He cites a finding from a 25-year review of child protection ADR that, even though the facilitator's role is "primarily process oriented", if facilitators do not understand in depth the system realities as well as the goals and objectives of child welfare services, such as permanency planning, "they are likely to be distrusted" by child protection social workers who appear as parties. Facilitators must therefore have sufficient substantive knowledge to be able to impart information typically needed during the ADR process. If they lack this, the essential aim of consensus building is unlikely to be achieved. Facilitators with substantive knowledge, as opposed to only process knowledge, are also better able to assist families achieve clarity about how the child protection system operates (Mayer, 2009:18). Since both process and substantive knowledge content are thus clearly important, these will be discussed further separately.

With regard to process, Barsky (2001:28), after a review of models of family mediation, found that no specific model is universally prescribed for training. This is because "research does not show which models are more effective". He thus recommends that, rather than focusing on stages for specific models, procedure training should focus more generally on what are typically the different stages of mediation and the functions performed at each. He identified the following as common stages: "preparation, orientation, storytelling, defining issues, exploring needs and interests, negotiating and problem solving, finalising an agreement and follow-up" (Barsky, 2001:33).

As with mediation, in family group ADR variants, process issues must be covered in training (Chandler \& Giovannucci, 2004:221). These will include the most common phases and role of the facilitator during each phase. Evans (2011) notes that training on the preparation phase is crucial. For example, facilitators must be trained to ensure that this phase is used to see whether it is likely that the child's voice may be suppressed. If so, a family member must be identified to facilitate and protect the child's voice (George Hull Centre, 2014).

In relation to training on the second fundamental aspect of substantive knowledge, for family group ADR variants "core philosophical assumptions and practice expectations" need to be incorporated (Chandler \& Giovannucci, 2004:221). From a review of the literature, the following emerge as essential in training programmes for all methods of child protection ADR: 
- knowledge of family dynamics and family systems theory (Association of Family and Conciliation Courts Guidelines, 2012; Hehr, 2007; Mayer, 2009; Savoury, Beals \& Parks, 1995);

- roles of parties and participants (Association of Family and Conciliation Courts Guidelines, 2012; California Rules of Court, 2014);

- how individualistic approaches to dispute resolution are different from collective approaches (Boniface, 2012; Ojelabi, Fisher, Cleak, Vernon \& Balvin, 2012);

- child protection legislation and system (Association of Family and Conciliation Courts Guidelines, 2012; Mayer, 2009);

- the legal framework for child protection intervention (Association of Family and Conciliation Courts Guidelines, 2012; Cunningham \& Van Leeuwen, 2005; Mayer, 2009);

- court process (Association of Family and Conciliation Courts Guidelines, 2012);

- issues related to intervention in child abuse and neglect (Association of Family and Conciliation Courts Guidelines, 2012; California Rules of Court, 2014; Mayer, 2009);

- typical impact of family violence, substance abuse, mental health issues (Association of Family and Conciliation Courts Guidelines, 2012; California Rules of Court, 2014; Mayer, 2009; Savoury et al., 1995);

- child development, attachment, psychological issues (Association of Family and Conciliation Courts Guidelines, 2012); Chandler \& Giovannucci, 2004; Mayer, 2009;

- diversity issues, cultural assessment (Association of Family and Conciliation Courts Guidelines, 2012; California Rules of Court, 2014; Giovannucci \& Largent, 2009; Ojelabi et al., 2012);

- power imbalances, gender roles (Cunningham \& Van Leeuwen, 2005; Ojelabi et al., 2012);

- treatment options and community resources (Association of Family and Conciliation Courts Guidelines, 2012; California Rules of Court, 2014; Cunningham \& Van Leeuwen, 2005);

- when to involve children (Association of Family and Conciliation Courts Guidelines, 2012; California Rules of Court, 2014; De Jong, 2009);

- understanding group processes (Giovannucci \& Largent, 2009);

- standards of conduct and ethics for mediators, (Association of Family and Conciliation Courts Guidelines, 2012; California Rules of Court, 2014).

A substantive knowledge syllabus must distinguish different case categories. For example, Hehr (2007:463) points out that ADR facilitators must be trained to be aware that "children's needs are different in child abuse cases". Concerning indigenous 
methods, Boniface (2012) questions whether current accepted knowledge taken from "Western countries" adequately addresses concerns in Africa. She concludes that an "intra-cultural model of mediation" should be developed in South Africa (Boniface, 2012:124). Generally, indigenous methods will require specialist knowledge training in, for example, attitudes of family members to community elders (Ojelabi et al., 2012).

As has been noted, aside from training in process and substantive knowledge, the third major content requirement is that covering skills and techniques. In relation to what skills are required for trainees, Barsky (2001:33) identified the more common skills and techniques for care and protection mediation as "reframing, focusing the parties on the future, focusing the parties on the best interests of the children, establishing ground rules for communication, using neutral language, managing the emotional climate, and ensuring that the parties view the process as fair". Skills common to most forms of care and protection ADR are:

- communication and mediation skills (Association of Family and Conciliation Courts Guidelines, 2012: 20; De Jong, 2009; Giovannucci \& Largent, 2009);

- skills in addressing power imbalances (Cunningham \& Van Leeuwen, 2005);

- assertiveness training, presentation of self (Hehr, 2007);

- conflict resolution skills (Association of Family and Conciliation Courts Guidelines, 2012; Savoury et al., 1995);

- working with multiple parties, (Association of Family and Conciliation Courts Guidelines, 2012; California Rules of Court, 2014; Giovannucci \& Largent, 2009);

- use of techniques from indigenous methods (Boniface, 2012; Ojelabi et al., 2012; Olson, 2009).

All skills training methods must be practical, and many are best achieved through role playing and case simulations (Savoury et al., 1995). Savoury et al. (1995:749) describe training in Nova Scotia which provided "participants with an opportunity to mediate true-to-life scenarios involving CPS workers who were invited to play the roles of family members and caseworkers". Hehr (2007:469) recommends that participants "be required to spend a minimum of twenty hours of role playing in mock mediations and participating in team mediations". She adds that "[b]ecause working with children may be the most challenging part, more time should be dedicated to the latter, where children are present". Videotaping the mock sessions, followed by feedback to participants, is also an excellent training tool (Savoury et al. 1995).

\section{Assessment}

It is important that the final assessment of participants and the award of a certificate be based on successful completion of the didactic and experiential work. Process and substantive knowledge can be assessed from written tests. However, skills will need to be assessed by observing candidates as they carry out hypothetical ADR exercises such as mock ADR role-playing (Hehr, 2007). Savoury et al. (1995:750) referred to this practical aspect as a "competency assessment". It is also possible to test candidates' 
skills by involving them as co-facilitators in real ADR situations (Chandler \& Giovannucci, 2004; Giovannucci \& Largent, 2009). Assessment need not be made on a simple "pass or fail" basis. Depending on how well candidates perform, some programmes allow for certification either as merely a co-ADR facilitator or, for the highest achievers, certification to practice as a solo facilitator. The former category of partially successful participants is allowed to co-facilitate to refine skills and they may then apply subsequently to upgrade their status to that of solo facilitator (Savoury et al., 1995).

\section{Continuing Education}

Giovannucci and Largent (2009:45) recommend that newly-qualified ADR facilitators be provided with opportunities to "observe actual cases". They suggest that comediation or mentoring are also important continuing education strategies. Continuing professional development is advocated to further advance skills and to remain up to date on changes to legislation and child welfare policies (Association of Family and Conciliation Courts Guidelines, 2012; California Rules of Court, 2014; Giovannucci \& Largent, 2009; Savoury et al., 1995). The AFCC Guidelines (2012:20) advocate the establishment of minimum requirements for the "continuing education and professional development of child protection mediators". The California Rules of Court (2014) mandate continuing education of at least twelve hours per year. In addition, De Jong (2009) advocates self-assessment and peer consultation on a regular basis.

\section{RECOMMENDATIONS}

The experiences elsewhere, as discussed above, provide useful inspiration for design of a South African training programme. Although many South African social workers gain extensive experience in care and protection matters, it is clearly essential that they receive specialised training if they are to work effectively as child protection ADR facilitators. It has been shown that ADR requires very different role functions from normal care and protection work. It is, in fact, unfair to expect social workers to undertake care and protection ADR without relevant training. Savoury et al. (1995:745) found that "child protective service (CPS) workers, although trained in social work, are not always prepared for such conflicts and have not necessarily received formal training in conflict resolution techniques as part of their professional education. This frequently puts CPS workers in a vulnerable position in attempting to resolve conflict situations".

Challenges in South Africa include the setting of realistic eligibility criteria and developing a spread of ADR programmes across the country. It is recommended that eligibility of social workers as candidates for care and protection ADR be based on the following prerequisites: a Bachelor of Social Work Degree, with at least 2 years' experience in statutory work with children and families. As has been shown, most programmes in other countries require a professional degree. Prior training and experience in family mediation, FGCs or other forms of ADR should also be considered as positive for eligibility. However, Giovannucci and Largent (2009) warn that not all family mediators make good child protection mediators. This suggests that other eligibility criteria are also important. As has been shown, personal characteristics and 
ability are also important eligibility criteria, and criteria on these will need to be developed for the South African context.

Training in care and protection ADR must provide candidates with relevant knowledge of process, substantive knowledge and skills. Accreditation guidelines must specify the length and content of training. The following aspects should be considered when developing an ADR training programme for South Africa.

- Beginning with generic training on ADR methodologies. This should include conflict resolution skills, assertiveness training and presentation of self (Hehr, 2007). The following factors which have been identified as increasing the vulnerability of participants must be included in the initial training: power imbalances, domestic violence, mental health issues and cultural considerations. After completion of this initial training, as in the Ontario system (discussed above), it may be possible to screen candidates and decide who may continue with child protection ADR training. Whether to include general family mediation training as a compulsory precursor to child protection mediation should also be explored.

- Training on the child protection system. This should include goals and objectives of child welfare services, developmental social welfare, knowledge of indigenous methods which build on the strengths of individuals, families and communities (Schmid, 2008:350), the impact of poverty and knowledge of resources. The substantive knowledge syllabus content for a South African programme must include training in legal processes and ADR provisions of the Act. It must also include training on factors that are positive or negative indicators for utilising ADR. Training on child participation should also be provided.

- Training in child protection ADR methods and processes. It is suggested that all eligible candidates should receive training in both mediation and FGCs. This will allow them to match the most appropriate method with each individual case. Given the different processes involved in child protection mediation and FGCs, a dedicated number of training hours per method must be determined. In addition, there must be a further determination of how many of these hours should be allocated to didactic work and how many to skills development. Training must also cover pre-hearing conferences and other lay forums. It should be possible, after assessment, to decide whether candidates successfully receive accreditation in all, or merely some, of the ADR methods taught.

It is particularly important that eligibility and training requirements are clearly set out and easy to administer. Processes that are too complicated to administer could result in unnecessary bureaucracy and stifle implementation.

\section{REFERENCES}

ASSOCIATION OF FAMILY AND CONCILIATION COURTS. 2012. Guidelines for Child Protection Mediation. [Online] Available: http://www.afccnet.org/Portals/0/ Guidelines for Child Protection Mediation.pdf. [Accessed 4/2/2014]. 
AUSTRALIAN LAW REFORM COMMISSION. 2012. Family violence: a national legal response (Report 114. Amended version of 19 July 2012). [Online] Available: www.alrc.gov.au/publications/23. [Accessed: 03/02/2014].

BAN, P. 2005. Aboriginal child placement principle and family group conferences. Australian Social Work, 58(4):384-394.

BARSKY, A. 2001. Understanding mediation from a social work perspective. Canadian Social Work Review, 18(1):25-46.

BONIFACE, A. 2012. A humanistic approach to divorce and family mediation in the South African context: a comparative study of Western-style mediation and African humanistic mediation. African Journal on Conflict Resolution, 12(3):101-129.

BROWN, L. 2003. Mainstream or margin? The current use of family group conferences in child welfare practice in the UK. Child and Family Social Work, 8:331-340.

CALIFORNIA RULES OF COURT 2014. Rule 5.518: Court-connected child protection/dependency mediation. [Online] Available: http://www.courts.ca.gov/cms/ rules.cfm. [Accessed: 04/02/2014].

CHANDLER, S.M. \& GIOVANNUCCI, M. 2004. Family Group Conferences: transforming traditional child welfare policy and practice. Family Court Review, 42(2):216-231.

CHILDREN'S COMMUNITY NETWORK, ONTARIO. 2014. Programs and Services: ADR-program description. [Online] Available: www.ccnsudbury.on.ca/ en/adr.html. [Accessed: 31/01/2014].

CUNNINGHAM, A. \& VAN LEEUWEN, J. 2005. Discussion guide for communities implementing child protection mediation. London ON: Centre for Children \& Families in the Justice System.

DE JONG, M. 2009. Child-focused mediation. In: BOEZAART, T. (ed) Child Law in South Africa. Claremont: Juta \& Co.

EDWARDS, L. 2009. Child Protection Mediation: a 25-year perspective. Family Court Review, 47(1):69-80.

EVANS, C.A. 2011. The public law outline and family group conferences in childcare practice. Child Care in Practice, 17(1):3-15.

FAMILY LIFE CENTRE. 2014. Building relationships and preserving family life. [Online] Available: www.familylife.co.za [Accessed: 10/03/2014].

FIRESTONE, G. \& WEINSTEIN, J. 2004. In the best interests of children: a proposal to transform the adversarial system. Family Court Review, 42(2):203-215.

GALLINETTI, J. 2012. The children's court. In: DAVEL, C.J. \& SKELTON, A.M. (eds) Commentary on the Children's Act. Claremont: Juta \& Co. 
GEORGE HULL CENTRE. 2014. Update on ADR Regulation and Family Group Conferencing. [Online] Available: www.georgehullcentre.on.ca/documents/FGC. ADR.doc. [Accessed: 06/02/2014].

GIOVANNUCCI, M. \& LARGENT, K. 2009. A guide to effective child protection mediation: lessons from 25 years of practice. Family Court Review, 47(1):38-52.

HEHR, A.M. 2007. A child shall lead them: developing and utilizing child protection mediation to better serve the interests of the child. Ohio State Journal on Dispute Resolution, 22(2):443-476.

HUNTSMAN, L. 2006. Family group conferencing in a child welfare context. NSW Department of Community Services. [Online] Available: http://www.community .nsw.gov.au. [Accessed: 31/01/2014].

JORDAN, K. 2009. Need to be heard: increasing child participation in mediation through the implementation of model standards. Family Court Review, 47(4):715-736.

KITCHING, M. 2014. Executive Director of Child Welfare Durban and District. Personal communication on 1 April 2014.

LUBIN, J. 2009. Are we really looking out for the best interests of the child? Applying the New Zealand model of family group conferences to cases of child neglect in the United States. Family Court Review, 47(1):129-147.

MAYER, B. 2009. Reflections on the state of consensus-based decision making in child welfare. Family Court Review, 47(1):10-20.

NATIONAL ACCREDITATION BOARD FOR FAMILY MEDIATORS. 2011. National Standards for Family Mediation. [Online] Available: http://www.usb.ac.za/disputesettlement/pdfs/NABFAM_Standards.pdf [Accessed: 10/03/2014].

OJELABI, L.A., FISHER, T., CLEAK, H., VERNON, A. \& BALVIN, N. 2012. A cultural assessment of family dispute resolution: findings about cultural appropriateness from the evaluation of a family relationship centre. Journal of Family Studies, 18(1):76-89.

OLSON, K.B. 2009. Family group conferencing and child protection mediation: essential tools for prioritizing family engagement in child welfare cases. Family Court Review, 47(1):53-68.

ONTARIO ASSOCIATION FOR FAMILY MEDIATION 2014. The Ontario Child Protection Mediation Roster Program. [Online] Available: www.oafm-cpmed.ca. [Accessed: 12/03/2014.

REPUBLIC OF SOUTH AFRICA. 2010. Children's Act 38 of 2005.

SAVOURY, G.R., BEALS, H.L. \& PARKS, J.M. 1995. Mediation in child protection: facilitating the resolution of disputes. Child Welfare, L IV(3):743-762.

SCHÄFER, L. 2011. Child Law in South Africa: domestic and International Perspectives. South Africa: LexisNexis. 
SCHMID, J.E. 2008. The story of South African child welfare: a history of the present. Canada: Wilfred Laurier University. (PhD Thesis)

SHEEHAN, R. 2006. Alternative dispute resolution in child protection matters: the Victorian experience. Australian Social Work, 59(2):157-171.

WEIGENSBERG, E.C., BARTH, R.P. \& GUO, S. 2009. Family group decision making: a propensity score analysis to evaluate child and family services at baseline and after 36months. Children and Youth Services, 31:383-390.

ZAAL, N. 2010. Party status in children's courts: a look at the implications for social workers. The Social Work Practitioner-Researcher, 22(3):292-306.

Prof Carmel $R$ Matthias, School of Applied Human Sciences, University of KwaZulu-Natal, Durban, South Africa. 